\title{
Perawatan luka pada anjing penderita demodekosis di Klinik Hewan Bogor Pet Center Bogor
}

\author{
Henny Endah Anggraeni ${ }^{1}$, Wily Widya Komara ${ }^{1}$, Feni Dwi Kartika Gulo ${ }^{2}$, Mustika Hidayanti ${ }^{2}$ \\ ${ }^{1}$ Program Studi Paramedik Veteriner, Sekolah Vokasi, Institut Pertanian Bogor, Bogor \\ ${ }^{2}$ Klinik Hewan Bogor Pet Center, Bogor
}

\begin{abstract}
Demodecosis is a skin disease caused by mites Demodex sp. The mites can cause itching and made scratching reflex and made skin damage or wound. Wound is a damage conditions in the skin tissues. Wound care for demodecosis of Pitbull mix dog at Bogor Pet Centre Clinic began with treatment the myiasis and clean the wound 2 times a day and the treatment continues until 19 days topically and orally. Wound healing works well.
\end{abstract}

\section{Keywords:}

Bogor Pet Centre, demodecosis, skin, wound healing.

\section{- PENDAHULUAN}

Demodekosis merupakan suatu penyakit kulit yang disebabkan oleh tungau Demodex sp (Hsu et al. 2009). Tungau tersebut dapat menimbulkan rasa gatal dan memicu refleks menggaruk. Garukan secara terus menerus dengan kondisi kuku yang tajam juga merupakan faktor yang dapat menyebabkan terjadinya luka. Luka terbuka yang bernanah dapat memicu lalat untuk hinggap dan bertelur. Kerusakan jaringan yang terinfeksi dapat menimbulkan bau yang khas dan menarik lalat betina untuk meletakan telurnya pada luka tersebut (Caissie et al. 2008). Hal tersebut merupakan faktor terjadinya myasis yang memberi efek negatif terhadap luka dan persembuhanya. Tujuan penulisan ini adalah menjelaskan prosedur perawatan luka pada anjing penderita Demodekosis yang mengalami miasis di Klinik Hewan Bogor Pet Center (BPC).

\section{- KASUS}

Anjing bernama jimbo (ras Pitbull mix, jantan, umur kisaran 4 tahun). Pengamatan dan pengambilan data dilakukan di Klinik Hewan Bogor Pet Centre (BPC), Ruko Lokatmala No. 3 Jl. Mayjen Ishak Djuarsa Loji, Kecamatan Bogor Barat, Kota Bogor, Provinsi Jawa Barat. Data primer didapatkan dengan melakukan perawatan luka, identifikasi luka terbuka dan wawancara dengan dokter hewan dan paramedis dalam proses perawatan luka, pada tanggal 15 Januari hingga 14 Februari 2019.

\section{- HASIL DAN PEMBAHASAN}

Luka yang terdapat pada tubuh anjing merupakan jenis luka terbuka kronis, dan mengalami myasis. Perawatan luka diawali dengan pengambilan larva lalat dengan menggunakan pinset dan larva dimasukkan ke dalam wadah yang berisi air tembakau (tembakau kering direndam dalam air hingga air rendaman berwarna kuning) dengan tujuan untuk mematikan larva tersebut. Ekstrak tembakau dapat mematikan serta mengeluarkan larva lalat pada jaringan hidup (McGraw \& Turiansky 2008).
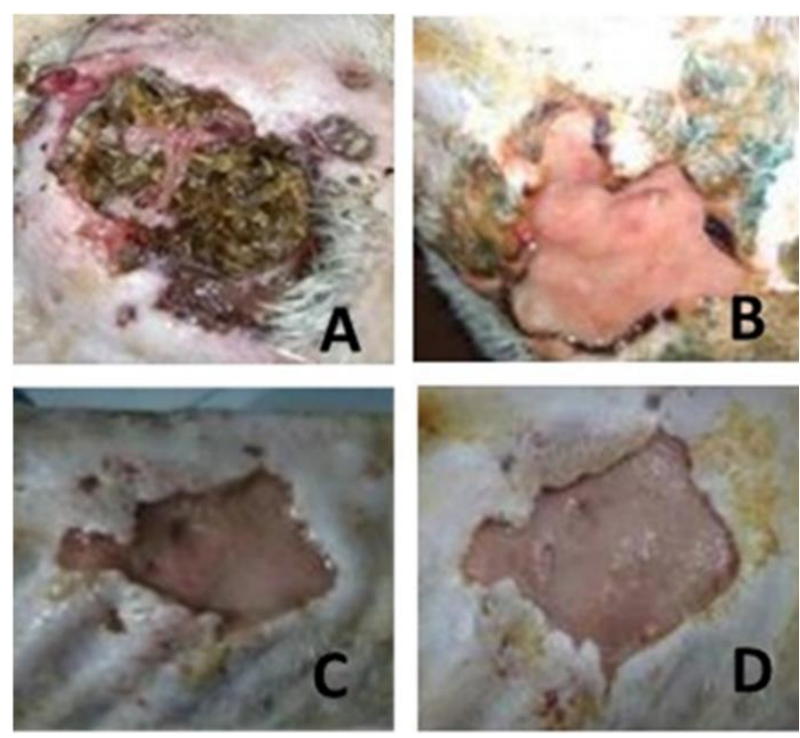

Gambar 1. Persembuhan luka (A) kondisi awal, (B) fase homeostasis dan inflamasi, (C) fase migrasi dan proliferasi, (D) fase maturasi

Luka dibersihkan sehari $2 \mathrm{x}$ dengan larutan $\mathrm{NaCl}$ fisiologis untuk membersihkan kotoran seperti debu, nanah, dan sel kulit mati atau nekrotik. Luka disemprot menggunakan Gusanex ${ }^{\circledR}$ (PT Animal Health Care, Indonesia) yang mengandung Dichlofention $1 \%$ yang dapat membasmi larva screw worm (Pratiwi et al. 2010). Semua larva lalat mati

Diterima: 15-01-2020 | Direvisi: 18-02-2020 | Disetujui: 22-02-2020

() 2020 CC-BY-SA. Ini adalah artikel Open Access yang didistribusikan berdasarkan ketentuan dari Creative Commons Attribution ShareAlike 4.0 International License (https://creativecommons.org/licenses/by-sa/4.0/). 
pada hari ke 3 (Gambar 1). Pengobatan demodekosis dilakukan dengan pemberian obat Adex ${ }^{\circledR}$ (PT Tri Daya Varuna, Indonesia) yang mengandung ivermectin, omega 3, omega 6, vitamin A, vitamin D dan kalsium secara per oral 1 $\mathrm{x}$ sehari. Luka diberi iodine tinctur yang mengandung bahan aktif povidone iodine $10 \%$ dan salep racik campuran dari Bioplasenton ${ }^{\circledR} \quad$ (PT Kalbe Farma, Indonesia) dan Gentamycin (PT Kimia Farma, Indonesia) secara topikal 1x sehari selama 19 hari untuk mempercepat persembuhan luka. Pemberian antibiotik Clanexi ${ }^{\circledR}$ (PT Sanbe Farma, Indonesia) yang mengandung bahan aktif amoxicillin dan asam clavulanat untuk membunuh mikroorganisme yang merugikan secara per oral.

Proses persembuhan luka ditunjukkan pada Gambar 1. Kondisi awal luka terlihat infestasi larva lalat (Gambar 1A), perubahan yang terjadi pada luka di hari ketiga merupakan fase homeostasis dan inflamasi (Gambar 1B). Fase homeostasis adalah pelepasan protein yang mengandung eksudat ke dalam luka menyebabkan vasodilatasi dan pelepasan histamin maupun serotin, serta menjaga kondisi luka agar tetap lembab (Purnama et al. 2017). Hari ke enam sel kulit mati terlepas dari permukaan luka mulai berubah menjadi warna rose. Perubahan tersebut disertai dengan pertumbuhan jaringan baru pada sekitar luka. Fase ini merupakan fase migrasi dan proliferasi (Gambar 1C). Hari ke dua belas perawatan (Gambar 1D) fase maturasi, pembentukan jaringan selular dan penguatan epitel baru (Purnama et al. 2017).

\section{SIMPULAN}

Perawatan luka diawali dengan penanganan myasis dan pembersihan luka dua kali sehari serta mengobatan luka dilakukan selama 19 hari secara topikal dan per oral.

\section{- INFORMASI PENULIS}

Penulis untuk Korespondensi *HEA: henny.ea12@gmail.com

Program Studi Paramedik Veteriner, Sekolah Vokasi, Institut Pertanian Bogor, Kampus IPB Cilibende Jl Kumbang No. 14 Bogor 16151, Jawa Barat, Indonesia.

\section{- PUSTAKA ACUAN}

Caissie R, Beaulieu F, Giroux M, Berthod F, Landry PÉ. 2008 Cutaneous myiasis: diagnosis, treatment, and prevention. Journal of oral and Maxillofacial Surgery. 66(3):560-568.

Hsu CK, Hsu MM, Lee JY. 2009. Demodicosis: a clinicopathological study. Journal of the American Academy of Dermatology. 60(3):453462.

McGraw TA, Turiansky GW. 2008. Cutaneous myiasis. Journal of the American Academy of Dermatology. 58(6):907-26.

Pratiwi A, Bimo W, Dianita DS, Haris FP, Imam H. 2010. Saleb Gusalin (Gusanex dan Penicilin) Sebagai Drugs Of Choice Yang Tepat Dalam Pengobatan Penyakit Belatungan (Myasis) Sapi. Jurnal Saintifika Gadjah Mada. 2(2):36-39

Purnama H, Sriwidodo, Soraya R. 2017. Review Sistematik. Proses Penyembuhan dan perawatan Luka. Jurnal. Fakultas Farmasi. Bandung. Universitas Padjajaran. 15(2):251-258. 